\title{
PEMBERIAN LAYANAN BIMBINGAN PRIBADI SOSIAL DALAM MENUMBUHKAN PERILAKU PROSOSIAL ANAK USIA DINI
}

\author{
Suharni \\ harnibk@gmail.com \\ Beny Dwi Pratama \\ benydwipratama86@yahoo.com
}

\begin{abstract}
Abstrak
Penelitian ini dilatarbelakangi oleh banyaknya anak yang kurang memiliki perilaku prososial terhadap teman atau lingkungannya. Melalui program pemberian layanan bimbingan pribadi sosial yang terencana diharapkan mampu menumbuhkan perilaku prososial anak usia dini. Penelitian ini dilakukan di Paud Kuncup Harapan. Penelitian yang digunakan adalah penelitian kualitatif dengan teknik pengumpulan data melalui wawancara, observasi dan dokumentasi.Observasi digunakan untuk mengetahui keadaan atau kondisi yang berkaitan dengan layanan bimbingan pribadi sosial dalam menumbuhkan perilaku prososial siswa. Observasi dilakukan pada saat kegiatan pembelajaran.Wawancara dalam penelitian ini adalah percakapan dengan maksud tertentu. Peneliti membuat format wawancara yang terkait dengan pelayanan bimbingan pribadi sosial terkait dengan perilaku prososial. Dengan pemberian layanan bimbingan pribadi sosial dalam kegiatan pembelajaran anak usia dini terdapat perubahan sikap terkait perilaku prosial mereka. Anak mulai bisa mengerti akan perilaku untuk peduli kepada orang lain. Ada 6 siswa sudah memiliki prilaku prososial yang baik dan konsisten, 3 siswa yang sudah mampu memiliki perilaku prososial tetapi kurang konsisten dan 3 siswa belum mampu memiliki perilaku prososial atas kesadarannya sendiri. Anak usia dini dapat menunjukkan perilaku sosialnya kepada teman, guru dan lingkungannya.
\end{abstract}

Kata Kunci: Layanan Bimbingan Pribadi Sosial, Perilaku Prososial, Anak Usia Dini

* Suharni dan Beny Dwi pratama dalah dosen Program Studi Bimbingan dan Konseling IKIP PGRI Madiun

\section{PENDAHULUAN}

Masa Usia dini merupakan masa emas pertumbuhan dan perkembangan sebab perkembangan berbagai aspek psiko-sosio biologi yang terjadi pada masa ini akan menjadi dasar perkembangan pada masa selanjutnya. Pada masa ini perkembangan jaringan otak anak mengalami peningkatan yang sangat 
pesat, oleh karena itu layanan pendidikan anak usia dini (PAUD) memegang peranan yang sangat strategis dalam mengoptimalkan semua potensi sesuai perkembangan anak.

Pada permendikbud No 137 Tahun 2014 tentang Standar pendidikan anak usia dini pasal 10 ayat 1 bahwa lingkup perkembangan sesuai usia anak meliputi aspek agama dan moral, fisik motorik, kognitif, bahasa, sosial emosional dan seni.

Upaya mencerdaskan anak sewajarnya dilakukan sedini mungin, agar anak tumbuh dan berkembang sebagai individu yang cerdas baik secara intelektual, emosional maupun spiritual.Selanjutnya, secara dini pula orang dewasa (guru dan orang tua) perlu memahami dan membantu membimbing anak agar berbagai aspek perkembangan, seperti fase dan tugas perkembangan mereka dapat tumbuh dan berkembang secara optimal.

Berangkat dari pemahaman manusia sebagai makhluk sosial yang tidak dapat lepas dari manusia yang lainnya, manusia dituntut untuk dapat berinteraksi sesuai dengan norma dan aturan yang berlaku. Untuk itulah individu harus mampu memahami emosi orang lain dan mampu memprediksi tindakan yang penting dalam bersosialisasi. Berbakal kemampuan memahami orang lain, individu akan lebihmudah menjalin persahabatan dengan orang lain. Salah satu bentuk perilaku yang terkait dengan memahami perspektif orang lain adalah perilaku prososial.

Syaodih (2012: 1) perilaku prososial perlu dimiliki sejak kecil sebagai suatu pondasi bagi perkembangan kemampuan anak dalam berinteraksi dengan lingkungannya secara lebih luas oleh karenanya perlu dikembangkan dan dibina selama proses pendewasaan.

Permasalahan yang timbul dilapangan terkait dengan perilaku prososial anak usia dini bahwa masih banyak anak-anak yang belum menunjukkan perilaku prososial seperti menolong teman yang jatuh, menolong teman yang sedang kesulitan, masih maunya menang sendiri yang ditandai dengan suka memerintah teman, kurang mampu bekerjasama dengan teman, mudah marah dan menangis apabila keinginannya tidak terpenuhi.

Layanan bimbingan merupakan bagian dan penunjang yang tak terpisahkan dari keseluruhan kegiatan pendidikan termasuk pada kegiatan pendidikan untuk anak usia dini dan mencakup seluruh tujuan dan fungsi bimbingan. Dilihat dari tujuan dan materinya, lingkup layanan bimbingan dan konseling anak usia dini disini menggunakan bimbingan pribadi sosial.

Bimbingan pribadi sosial diarahkan untuk memantapkan kepribadian dan mengembangkan kemampuan anak dalam menangani masalah-masalah dirinya. Bimbingan 
pribadi ini diberikan dengan cara menciptakan lingkungan yang kondusif, interaksi pendidikan yang akrab, mengembangkan sistem pemahaman diri dan sikap-sikap positif, serta keterampilanketerampilan sosial pribadi yang tepat.

Berdasarkan hal tersebut diatas dapat dijadikan sebagai gambaran bahwa perilaku prososial sangat penting untuk dimiliki dan dikembangkan sejak usia dini, dengan memberikan layanan bimbingan pribadi sosial agar selanjutnya dapat dijadikan pemecahan masalah.

Bimbingan pribadi sosial adalah proses bantuan yang diberikan kepada individu yang bertujuan untuk membantu individu tersebut memahami dirinya sendiri, mengetahui bagaimana caranya berinteraksi dengan orang lain dan bersikap dengan mempertimbangkan keberadaan orang lain, memahami etika dan bersikap santun, membina sebuah keluarga serta memahami peran dalam tanggungjawab sosial(Gordon, 2013:13)

Bimbingan pribadi sosial ini dimaksud untuk mencapai tujuan tugas perkembangan pribadi sosial anak dalam mewujudkan pribadi yang mampu menyesuaikan diri dan bersisialisasi dengan lingkungan secara baik (Syaodih, 2010:12).Bimbingan pribadi sosial merupakan bimbingan untukemmbantu anak dalam memecahkan masalah-masalah pribadi sosial.Biasanya pada masa anak-anak yang tergolong dalam masalah pribadi sosial adalah masalah hubungan dengan sesama teman, dan guru atau pendamping ditempati belajar, pemahaman sifat dan kemampuan diri, penyesuaian diri dengan lingkungan sekitar dan masyarakat tempat tinggal mereka, dan penyelesaian konflik.

Bimbingan pribadi sosial diarahkan untukmemantapkan kepribadian dan mengembangkan kemampuan anak dalam menangangi masalah-masalah dirinya.Bimbingan ini merupakan layanan yang mengarah pada pencapaian pribadi yang seimbang dengan memperhatikan keunikan karakteristik pribadi serta ragam permasalahan yang dialami oleh anak.

Bimbingan pribadi sosial diberikan dengan cara menciptakan lingkungan yang kondusif, interaksi pendidikan yang akrab, mengembangkan sistem pemahaman diri dan sikap-sikap yang positif, serta keterampilan-keterampilan sosial pribadi yang tepat.

Pada kegiatan pendidikan anak usia dini, anak-anak-anak yang memiliki kemampuan pribadi sosial yang baik biasanya terfleksi dalam kemampuan anak untuk melakukan kegiatan-kegiatan sebagai berikut ini:

a. Kemampuan berempati pada teman-temannya 
b. Mengorganisasi teman-temannya untuk melakukan tugas

c. Mampu mengenali dan membaca pikiran orang lain

d. Memiliki banyak teman dan mampu menjalin hubungan dengan teman-temannya

e. Cenderung mudah memahami perasan orang lain

f. Sering menjadi pemimpin diantara tema-temannya

g. Memiliki perhatian yang besar kepada teman-temannya sehingga acap kali mengetahui berita-berita di seputar mereka.

Guru atau pendamping dapat mengembangkan kemampuan pribadi sosial anak dengan cara dapat distimulasi melalui kegiatan bermain. selama bermain anak-anak berinteraksi dengan sebaya dan guru atau pendamping mereka. Stimulasi tersebut dapat terjadi karena pada saat bermain anak-anak melakukan kegiatan sebagai berikut:

a. Mempraktikkan keterampilan berkomunikasi baik verbal maupun non verbal dengan cara mengasosiasikan peran, mencoba memperoleh keuntungan saat bermain atau mengapresiasikan perasaan teman man.

b. Merespon perasaan teman sepermainan di samping menunggu giliran dan berbagai materi serta pengalaman.

c. Bereksperimen dengan peranperan di rumah, sekolah dan komunitas dengan menjalin kontak dengan kebutuhan dan kehendak orang lain.

d. Mencoba melihat sudut pandang orang lain. Begitu anak bersentuhan dengan konflik tentang ruang, waktu, materi dan aturan, merekamembangun strategi resolusi konflik secara positif.

Idris (2015: 105) menjelaskan layanan pribadi sosial pada pendidikan anak usia dini adalah:

a. Mengenalkan ciri-ciri yang ada dalam diri sendiri, mengenalkan ciri khusus orang lain serta menunjukkan makna sikap yang baik dan yang tercela

b. Mengenalkan cara hidup sehat melalui makan makanan yang bergizi serta melakukan kegiatan olah raga secara teratur, serta menjaga kebersihan.

c. Mengenalkan cara mengungkapkanperasaan bahagia dan sedih, serta memberikan gambaran berbagai perasaan dalam berbagai situasi

d. Membimbing peserta didik menciptakan dan memelihara persahabatan, serta menjelaskan makna dari kerjasama.

e. Membimbing peserta didik mengenali kecakapan yang dimilikinya, melatih cara mengambil keputusan, menjelaskan perlunya memiliki beberapa pilihan sebelum mengambil keputusan dan mengenalkan akibat dari keputusan yang diambil. 
Yusuf, S \&Nurikhsan, A. J.(2006: 14), secara rinci menyebutkan tujuan yang ingin dicapai dari bimbingan pribadi sosial antara lain:

a. Memiliki komitmen yang kuat dalam mengamalkan nilai-nilai keimanan dan ketaqwaan kepada Tuhan Yang Maha Esa, baik dalam kehiduan pribadi, keluarga, pergaulan dengan teman sebaya, sekolah/madrasah, tempat kerja, maupun masyarakat pada umumnya.

b. Memiliki sikap toleransi terhada umat beragama lain, dengan saling menghormati dan memelihara hak dan kewajibannya masing-masing

c. Memiliki pemahaman tentang irama kehiduan yang bersfat fluktuatif antara yang menyenangkan (anugerah) dan yang tidak menyenangkan (musibah), serta mampu meresponnya secara positif sesuai dengan ajaran agama yang dianut.

d. Memiliki pemahaman dan penerimaan diri secara obyektif dan konstruktif, baik yang terkait dengan keunggulan maupun kelemahan; baik fisik maupun psikis.

e. Memiliki sikap positif atau respek terhadap diri sendiri dan orang lain

f. Memiliki kemampuan untuk melakukan pilihan secara sehat

g. Bersikap respek terhadap orang lain, menghormati atau menghargai orang lain, tidak melecehkan martabat atau harga dirinya.

h. Memiliki rasa tanggungjawab, yang diwujudkan dalam bentuk komitmen terhadap tugas atau kewajibannya.

i. Memiliki kemmauan berinteraksi sosial (human relationship), yang diwujudkan dalam bentuk hubungan persahabatan, persaudaraan, atau silaturahmi dengan sesama manusia.

j. Memiliki kemampuan dalam menyelesaikan konflik (masalah) baik bersifat internal (dalam diri sendiri maupun dengan orang lain.

k. Memiliki kemampuan untuk mengambil keutusan secara efektif.

Perilaku pada dasarnya berorientasi pada tujuan (Goal Oriented) dengan kata lain, perilaku kita ada umumnya dimotivasi oleh suatu keinginan untuk mencapai tujuan tertentu. Adapun tujuan spesifik, tidak senantiasa diketahui secara sadar oleh sang individu. Unit dasar perilaku adalah sebuah aktivitas, sesungguhnya kita dapat menyatakan bahwa perilaku merupakan suatu seri aktivitasaktivitas.

Perilaku prososial menurut William yaitu perilaku yang memiliki intensi untuk mengubah keadaan fisik ataupsikologis menerima bantuan dari kurang baik menjadi lebih baik, dalam arti secara 
mental maupun psikologis (Dyaksini, 2003).

Menurut Bringham (dalam Dayaksini, 2003) menyatakan bahwa perilaku prososial mempunyai maksud menyumbang kesejahteraan orang lain. dengan kedermawanan, persahabatan, kerjasama, menolong, menyelamatkan dan pengorbanan merupakan bentuk-bentuk prilaku prososial.

Dari beberapa pendapat para ahli tentang perilaku prososial diatas, maka ditegaskan bahwa yang dimaksud dengan perilaku prososial dalam konteks penelitian ini adalah membantu orang lain dengan cara meringankan konteks penelitian ini adalah membantu orang lain dengan cara meringankan beban fisik atau psikologi orang tersebut, memperhatikan kesejahteraan orang lain tanpa memikirkan kepentingan tana memikirkan kepentingan sendiri, dan ikut menyokong dengan tenaga pikiran.

Adapun jenis perilaku prososial menurut Mussen (dalam Nashori, 2008) meliputi:

a. Menolong, yaitu membantu orang lain dengan cara meringankan beban fisik atau psikologi orang tersebut. Membantu untuk meringankan beban enderiaan, kesukaran (Tim penyusun pusat Bahasa, 2005)

b. Berbagi rasa, yaitu kesediaan untuk ikut merasakan pada yang dirasakan orang lain, didorong oleh emosinya seolah-olah dia ikut mengambil bagian dalam gerakan-gerakan yang dilakukan orang lain.

c. Kerjasama, yaitu melakukan pekerjaan atau kegiatan secara bersama-sama berdasarkan keseakatan untuk mencvaai tujuan bersama pula. Kegiatan atau usahayang dilakukan oleh beberapa orang (badan, lembaga) untuk mencapai tujuan bersama.

d. Menyumbang, yaitu berlaku murah hati keada orang lain. Ikut menyokong dengan tenaga dan pikiran, memberikan sesuatu keada orang yang sedang tertimpa musibah

e. Memperhatikan kesejahteraan orang lain. Hasrat untuk meolong orang lain tanpa memikirkan kepentingan sendiri.

Dalam penelitian ini memfokuskan jenis-jenis perilaku perilaku sosial anak usia dini dengan bentuk-bentuk perilakunya yaitu: perilaku membantu, perilaku berbagi dan perilaku menghibur. Bentukbentuk perilaku membantu adalah membantu teman menyelesaikan tugas, membantu teman yang kesulitan membuka tutup bekal makanan, mengambil dan mengembalikan barang milik teman yang jatuh. Bentuk-bentuk perilaku berbagi adalah menawarkan makanan miliknya kepada teman, berbagi menggunakan alat permainan yang sama, berbagi tempat saat kegiatan mencuci tanganbersama. Bentuk-bentuk perilaku menghibur 
adalah menanyakan alasan teman bersedih, meletakkan tangan di bahu teman, memberikan pelukan dan menghapus air mata teman.

\section{METODE PENELITIAN}

Penelitian ini adalah penelitian kualitatif, yaitu penelitian yang bermaksud untuk memahami keadaan tentang apa yang dialami oleh subjek penelitian misalnya perilaku, persepsi, motivasi, tindakan, secara holistik, dan dengan cara deskripsi dalam bentuk katakata dan bahasa, pada suatu konteks khusus yang alamiah dan dengan memanfaatkan berbagai metode ilmiah(Moleong,2010: 6)

Subjek penelitian adalah keseluruhan dari sumberinformasi dan menunjukan pada orang atau individu atau kelompok yangdijadikan unit atau satuan khusus yang diteliti.Subjek penelitian yangdimaksudadalah informan atau sumber data, yaitu orang yang meresponatau menjawab pertanyaan peneliti.Adapun yang menjadi subjekpenelitian adalah siswa, guru, dan orang tua.Sedangkan objek penelitian adalah data apa saja yang akan dicari(digali) dalam penelitian.(Arikunto, 1991:17).Objek dalam penelitian ini adalah layanan bimbingan pribadi sosial dalam menumbuhkan perilaku prososial anak usia dini.

Untuk memperoleh data yang diharapkan, peneliti menggunakanteknik beberapa pengumpulan data.Adapun teknik pengumpulan datayang digunakan dalam penelitian ini adalah sebagai berikut:

1. Metode observasi adalah suatu pengamatan dan penulisandengan sistematis terhadap gejala-gejala atau objek yang diteliti. (Hadi S, 1984:141). Metode ini dipakai untuk memperoleh data yang belum terdapatdalaminterviewdan

dokumentasi. Teknik observasi yangdipergunakan dalam penelitian ini adalah observasi partisipan, yaitupeneliti ikut ambil bagian dalam kegiatan yang dilakukan orang yangdiobservasi.Observasidigunakan untuk mengetahui keadaan ataukondisi yang berkaitan dengan layanan bimbingan pribadi sosial dalam menumbuhkan perilaku prososial siswa.Observasi dilakukan pada saat kegiatan pembelajaran.

2. Wawancara adalah percakapan dengan maksud tertentu.Percakapan itu dilakukan oleh dua pihak, yaitu pewawancara(interviewer)yangmeng ajukan pertanyaan dan terwawancara(interview) yang memberikan jawaban atas pertanyaan itu. Dalam penelitian ini peneliti membuat format wawancara yang terkait dengan pelayanan bimbingan pribadi sosial terkait dengan perilaku prososial.

Analsis data adalah proses pengorganisasian dan mengurutkan data kedalam pola, kategori dan satuan dasar sehingga dapat 
ditemukan tema dan dapat dirumuskan hipotesis kerja seperti yang disarankan oleh data. Dalam rangka menganalisis data-data yang diperoleh dari hasil penelitian maka disini diterapkan metode analisis data kualitatif. Dalam analisis data tersebut digunakan teknik analisis deskriptif kualitatif yaitu analisis data yang memberikan predikat pada variabel yang diteliti dengan kondisi yang sebenarnya. (Arikunto, 1990:353).

Sedangkan analisis data dari penelitian ini, dilakukan berdasar analisis deskritif. Analisis tersebut terdiri dari tiga alur yang berinteraksi yaitu reduksi data, penyajian data dan penarikan kesimpulan.

\section{HASIL PENELITIAN}

Pemberian layanan bimbingan pribadi sosial yang diberikan oleh guru pada anak adalah melalui kegiatan seperti biasa, namun dalam kegiatan tersebut dimasukkan hal-hal yang berkaitan dengan bimbingan pribadi sosial terkait dengan menumbuhkan sikap perilaku prososial anak usia dini. Sejauh ini guru sudah melakukan layanan bimbingan namun belum tersistematis. Dengan penelitian ini guru dibantu untuk membuat rencana pemberian layanan bimbingan pribadi sosial.

Bentuk-bentuk perilaku prososial anak usia diniyaitu menunjukkan kepedulian terhadap teman yang sedang mengalami kesusahan, perilaku membantu, mampu menceritakan perasaan teman selama konflik, berbagi sesuatu dengan orang lain, memberikan sesuatu kepada orang lain, bergiliran tanpa rewel, memenuhi permintaan tanpa "rewel", membantu orang lain mengerjakan tugas, membantu orang lain yang membutuhkan pertolongan.Dalam pelaksanaannya perilaku prososial tersebut dikelompokan menjadi 3 kelompok yaitu perilaku membantu, perilaku berbagi dan perilaku menghibur.

Berdasarkan hasil penelitian, bentuk perilaku membantu teman ditunjukkan melalui kegiatan mereka melalui membantu teman menyelesaikan tugas saat bermain di sentra, membantu teman yang kesulitan membuka tutup bekal makanan saat kegiatan makan bersama, mengambil dan mengembalikan barang milik teman yang jatuh pada saat bermain.

Bentuk-bentuk perilaku berbagi dapat ditunjukkan menawarkan makanan yang dimilikinya kepada orang di sekelilingnya, berbagi saat menggunakan alat permainan yang sama di sentra berman, berbagi tempat saat kegiatan mencuci tanganbersama.

Perilaku prososial menghibur mereka tunjukkan dengan menanyakan alasan teman saat temannya sedang bersedih, menggandeng teman untuk diajak bersama, menghibur teman dan 
memberikan pelukan agar temannya tenang.

Dengan pemberian layanan bimbingan pribadi sosial dalam kegiatan pembelajaran anak usia dini terdapat perubahan sikap terkait perilaku prosial mereka. Anak mulai bisa mengerti akan perilaku untuk peduli kepada orang lain. Ada 6 siswa sudah memiliki prilaku prososial yang baik dan konsisten, 3 siswa yang sudah mampu memiliki perilaku prososial tetapi kurang konsisten dan 3 siswa belum mampu memiliki perilaku prososial atas kesadarannya sendiri. Anak usia dini dapat menunjukkan perilaku sosialnya kepada teman, guru dan lingkungannya.

Penerima perilaku prososial dari anak prasekolah adalah orang-orang yang sering berinteraksi dan dekat dengan mereka seperti anggota keluarga, guru maupun teman sekelas anak. Hasil penelitian ini sesuai dengan pernyataan Damon, Eisenberg dan Hoffman (dalam Ormrod, 2008:135) bahwa pada awal masa kanak-anak, anak menunjukkan empati terhadap orang-orang yang mereka kenal seperti teman sekelas maupun sahabat. Perbedaan dalam bentuk maupun tingkatan perilaku prososial anak prasekolah. dipengaruhi oleh tahapan perkembangan anak, strategi pembelajaran nilai perilaku maupun faktor-faktor dari lingkungan anak yang mempengaruhi kesempatan anak untuk mengembangkan perilaku prososial.

\section{KESIMPULAN DAN SARAN}

Fakta yang disimpulkan dalam penelitian ini adalah dengan adanya pemberian layanan bimbingan pribadi sosial dapat menumbukan perilaku prososial anak usia dini. Perilaku prososial anak usia dini dikelompokkan dalam dalam perilaku membantu, berbagi dan menghibur. Dalam diri anak mulai tumbuh rasa prososial terhadap teman, guru, dan juga lingkungannya. Kesimpulan lain dalam penelitian ini meliputi faktorfaktor yang dapat membantu anak dalam pembelajaran perilaku prososial anak yaitu orang tua, lingkungan, guru dan lembaga AUD.

Saran bagi guru untuk selalu memberikan layanan bimbingan anak usia dini secara konsisten dan terstruktur agar dalam pelaksanaannya dapat dievaluasi dengan maksimal. Bagi lembaga diharapkan dapat memberikan kesempatan kepada warga lembaga dengan memberikan perlengkapan sarana dan prasarana yang sesuai. Untuk peneliti selanjutnya adalah dapat mengkaji mengenai pemberian layanan lain yang dapat menumbukan kemampuan prososial anak usia dini. 


\section{DAFTARPUSTAKA}

Dayakisni, T dan Hudaniah. 2006. Psikologi Sosial. UMM Press

Hadi S. 1988. Statistik. Yogyakarta: Fakultas Psikologi UGM 2001. Metodologi Researd Jilid 2. Yogyakarta: Andi

Idris. 2015. Bimbingan dan Konseling (Implemtasi pada Pendidikan Anak Usia Dini. Jakarta: Luxima.

Mussen, .H. Conger, J.J And Kagan, J. (1989) Child develoment and ersonality (Fifth Edition). Haper and row publisher.http://digilib.uinsby.ac .id/10881/5/bab\%202.pdf diakses tanggal 12 Oktober 2016
Nuryanti Lusi. 2008. Psikologi Anak. Jakarta: Indeks

Ormord J,E. 2008. Sikolgi Pendidikan Jilid I. Jakarta: Erlangga

Petmonodewo,S. 2003. Pendidikan Anak Prasekolah. Jakarta: PT. RinekaCipta.

Prastiti Binar. 2008. Psikologi Anak Usia Dini. Jakarta: Indeks.

Sarwono, S.W. 2002. Psikologis Sosial Individu dan teori-teori sikologi sosial. Jakarta: Balai pustaka.

Syaodiah, Agustin. 2010. Bimbingan Konseling Anak Usia Dini. Jakarta:UT.

Yusuf, S \& Nurikhsan, A, Juntika.2006. Landasan Bimbingan dan Konseling. Bandung. Remaja Rosdakarya. 